it is not the same as Clausastraa = Plerastraca Pratti, Edw. \& H. The type specimen of Plerastroa Pratti, Edw. \& H., has a columella, and the authors of the genus did not describe it as having an essential columella. Bathyconia, Tomes : nothing was stated in the work called "A Revision of the Genera of Madreporaria" about the similarity of this genus and Stylosmilia; this is a statement difficult of explanation.

Every one of these numerous statements is made in opposition to the opinions of Mr. Tomes. Proper acknowledgment is made regarding the useful knowledge conveyed by Mr. T'omes about the localities of corals and the zones which some frequent.

The author of this communication agrees with Mr. Tomes on two points: Mr. Tomes has shown that, owing to the matrix of Cyclolytes Lycetti, Dunc., not being sufficiently removed, the form is his Dimorphastraa dubia, and that properly the generic name should be Dimorpharaa. Again, Mr. Tomes has raised much doubt in the author's mind where a species is placed by him under the genus Lepidophyllia, Dunc., should be placed; probably it will have to come within Donacosmilia, as stated by Mr. Tomes; but Donacosmilia requires careful working out.

3. "On the Astrocoenice of the Sutton Stone of the Infra-Lias of South Wales." By Prof. P. Martin Duncan, M.B., F.R.S., F.G.S.

The species which were placed in the genus Astrocoenia, and which came from the Sutton Stone and Brocastle deposits of the Infra-Lias of South Wales, were re-examined in the instance of A. gibbosa, A. insignis, A. parasitica, and A. plana (Dunc.). These species were originally described by the author in his 'Monograph of the British Fossil Corals,' second series, Pal. Soc. 1867, pt. iv. No. 1, and were illustrated. A good specimen of $A$. gibbosa is described, and its structures are shown to be strictly Astroconian. The different states of the corallites produced by various conditions, such as growth and gemmation, were explained. The same course was taken with reference to $A$. insignis and $A$. parasitica, and the density of the united walls was shown to have nothing to do with any intermural structure or coenenchyma in that sense.

A. plana was critically examined, and as it has all the characters of typical Astroconice, it remains in that genus with the others.

\title{
CORRESPONDFINOF.
}

\section{PALEONTOLOGICAL NOMENCLATURE.}

Sir,-With your permission I wich to present some remarks on the review of certain of my papers which $\mathrm{Mr}$. Lydekker published in the number of the Geological Magazine for October, 1885. The author of the review in question does me the honour to agree with me in my determinations of affinities, but he expresses general disapproval of my systematic methods. While I am much gratified at the agreement in more important matters thus expressed or inplied, I think it very desirable that there should be a larmony of 
action between naturalists in questions of classification and nomenclature. Scientific truth is involved in the former, and convenience in the latter.

In the first place I shall be sustained in differing from Mr. Lydekker whenever he fails to comply with that bulwark of the language of science, the law of priority. Except in the matter of the termination of the family name in idoe, and its derivation from some genus embraced in it, any name proposed first and accompanied by a definition, must be used in preference to any later name. I take it that this rule applies to all scientific terms whatsoever, which belong to any object, or definite idea abstracted from objects, provided the name be not false in its significance. Hence it will not be proper to yield to mere preferences, as for instance that of Mr. Lydekker, who would rather name orders and suborders from some genus which they contain, when other names have already been proposed in accordance with the rules.

In the application of this rule to the use of names for divisions of higher rank than families, room for the exercise of some discretion may be found. If a name be applied by its author to a group, there are two ways of learning what the proposer of the name had in view or the idea he intends to express; or, in other words, what he would include within its limits. One indication is to be found in his diagnosis; the other in the contents of described objects which he embraces in it. I claim, and I find that custom sanctions the claim, that the name should be retained for the division thus indicated, and for nothing else; and if both diagnosis and content do not represent any natural or tenable division, that the name should be dropped. In insisting on the applicability of diagnosis or content to something real, as the ground of the acceptance of a proposed group and of its name, I of course do not expect completeness in either of the conditions. In fact, these characteristics are never to be expected in the early stages of science. But incompleteness is not falsity. An example of a false division with a false diagnosis is to be found in the supposed order of Pachydermata, the name of which is positively rejected, and is not applied to one of those fragments of it which are natural divisions. Another false group is the Theriodonta, which was applied to some South African reptiles of Permian age. The definition, based on the dentition, does not define an order, and is common to more than one family, and the contents of the division agree with the definition. As types with grinding teeth clearly belong to the same order and suborder, there seems to be no place for the name.

To apply these propositions to the cases found in my papers and eriticized by Mr. Lydekker. While the Condylarthra do agree generally with the Hyracoidea, the differences are so important, especially in the form of the ungual phalanges, that I cannot refer them to the same suborder at least. Nor am I justified in applying the term Hyracoidea to the two divisions combined, as they certainly must be, for the group Hyracoidea has already a meaning and currency which it is not wise to attempt to disturb. Should I do so, 
the result would be more complex than that which I have preferred, for not only would the significance of the name Hyracoidea be changed, but I would have to make a new name for the Hyracoidea proper of older authors. The same reasoning applies to the case of the Insectivora. I must either change the significance of the now generally adopted term, or give a new name to the major division of which it forms only a part.

I now come to a second branch of the subject, and that is, the question of the definition of divisions. I lay down the principle, which is, I believe, a generally accepted one, that classification consists of precise definitions; and that the aim of the systematist should be to attain as great precision as the nature of the case will permit. The fact that all definitions which separate adjacent grouns will be ultimately found to be fallible, does not permit us to fall into inexact and inconsistent methods of definition. Any absolute difference in the number of parts must be noticed in the system as indices of the steps on the lines of descent. It is only proportions, dimensions, and texture which define species, as represented by their fossil remains. Any system which places animals with four digits in the same genus with others possessing three digits, is inexact. Any system which places animals with four premolar teeth in the same genus with those with three premolars is inexact, unless it can be shown that some species has indifferently three or four premolars. A system which includes animals with a scapholunar bone in the same division with animals with distinct scaphoid and lunar bones, is inexact. I think it will be ultimately agreed that animals with tritubercular superior molars must be more widely separated from those with quadrituberculars, than has hitherto been accepted. Nevertheless I admit that every character loses its value somewhere because of variability. But cases where such are not variable must be carefully distinguished from those where they are.

To again illustrate this point from those brought forward by $\mathrm{Mr}$. Lydekker. My critic "prefers" to arrange the Creodonta with the Carnivora, although they have no scapholunar bone. Now, I ask, what will be the definition of the order Carnivora, if we reject this character? There will be none, as the latter constitutes the only bond of union between its diverse forms. As if an unconscious cerebration opposed this view, Mr. Lydekker maintains the division Creodonta, but gives it a new name, "Carnivora primigenia," a name to which the law of priority opposes an objection. Secondly, on any character at present known the division called Insectivora is heterogeneous, and so soon as exact definitions are demanded, it requires subdivision. ${ }^{1}$ In order to distinguish these subdivisions as a whole, with the allied ones, which are clearly neither Edentata, Chiroptera nor Rodentia, I applied to them all, as an order, the name Bunotheria. This group is as definable as any of the others named, and has equal rank. It is the primitive form of placental unguiculate mammal, just as the Taxeopora is the primitive type of primitive ungulate mammal.

1 Some of this work remains to be done. 
I must now explain my use of the term Ungulata. Lamarck in his Philosophie zoölogique, of which the first edition was published in 1809, distinguished the mammalia into Exongulés, Amphibies, Ongulés, and Onguiculés. Of these, the Ongulés is a natural division which has been adopted by Cuvier, Owen (Odontography) and many other zoölogists, and has been current in zoölogical literature for half a century before it was applied by modern authors to a different and more restricted group (my Diplarthra), in opposition, as I believe, to the law of priority. In fact the distinction of the mammalia into Unguiculata, Ungulata, and Mutica was employed by Linnæus in the twelfth edition of the Systema Naturæ, about a century earlier than the term Ungulata as preferred by Mr. Lydekker. ${ }^{\mathbf{I}}$ And for placental gyrencephalous mammalia this classification is as natural as any one which has been proposed, and is the only one available for palæontologists. In concluding, I refer to another attempt at change of a long-standing and generally-accepted name by modern authors. I refer to the name Batrachia, which it is sought to replace by the term Amphibia. Although the latter is the better name, it has not the claim of priority by a half century at least. Although the early definitions were imperfect, the contents of the class were then the same as now. The division Batrachia, used by Lamarck and Cuvier, is uniformly employed in the herpetological literature of the last half century, except by a few German authors (e.g. Wagler), who combined them with the Reptilia in one division under the name Amphibia. Not only has the name Amphibia no claim on the ground of priority, but the diverse uses to which it has been put also render its use undesirable.

Philadelphia, Oct. 30, 188 s.

E. D. CoPE.

OBITUARY.

WALTER FLIGHT, D.SC.(LOND.), F.R.S., \&C.

Born 21st January, 1841; Died 4th November, 1885.

THE close of this year has witnessed the termination of another bright and promising life, ended all too soon for the hopes and expectations of his many friends.

Walter Flight was the son of William P. Flight, of Winchester, in which city he was born on the 21 st January, 1841. He was sent, after a period of pupilage at home, to Queenwood College,

I There is one noteworthy exception to this argument, viz. where Mr. Lydekker remarks that "Archonodon appears to us to be a form not improbably connecting the bunodont ungulates like Elotherium (with which it has been classed) with the unguiculate mammals," etc. Now this proposition is in opposition to theoretical and aetual mammalian phylogeny, as I have remarked in the American Naturalist, 1884, p. 718. It is impossible for any Artiodactyle mammal like Elotherium to have direct connection with an unguiculate. The genealogical line must pass backwards through a taxeopod line, and then downward into or through the bunotherian, to complete such a connection. 